\title{
Religion as a Social Determinant of Maternal Health Care Service Utilisation in Nigeria
}

\author{
Bola L. Solanke ${ }^{a}$, Olusegun A. Oladosu ${ }^{b}$, Ambrose Akinlo $^{c}$ and Samson O. Olanisebe \\ a Department of Demography and Social Statistics, modebolasolanke@gmail.com \\ ${ }^{\mathrm{b}}$ Department of Religious Studies, adeb12345@yahoo.com \\ ${ }^{\mathrm{c}}$ Department of Demography and Social Statistics, akinloa@oauife.edu.ng \\ ${ }^{\mathrm{d}}$ Department of Religious Studies, soolanisebe@yahoo.com \\ Obafemi Awolowo University, Ile-Ife, Nigeria
}

\begin{abstract}
This study examines the relationship between religious affiliation and utilisation of maternal health care services using 2013 Nigeria Demographic and Health Survey data. The outcome variable is utilisation of maternal health care service measured by antenatal care and place of delivery. The explanatory variables were religion and three purposively selected social determinants of health, namely the social gradient, work condition and social exclusion. The chi-square test and multinomial logistic regression were applied. Result show that $50.7 \%$ had the recommended 4 or more antenatal care visits; $23.4 \%$ and $13.5 \%$ respectively utilise public and private sector facilities for their most recent child delivery. The relative risk of having 4 or more antenatal visits reduce by a factor of 0.7863 for Muslim women $(p<0.05)$, and increase by a factor of 5.3806 for women in higher social ladder $(p<0.01)$. Religion should be integrated into the social determinants of health framework.
\end{abstract}

Keywords: Religion, maternal, health care, utilisation, women, social determinant

\section{Résumé}

Cette étude examine la relation entre l'appartenance religieuse et l'utilisation des services de soins de santé maternelle à l'aide des données de 2013 au Nigeria enquêtes démographiques et sanitaires . La variable de résultat est l'utilisation des services de soins de santé maternelle mesurée par les soins prénatals et lieu de livraison. Les variables explicatives sont la religion et trois déterminants sociaux choisis à dessein de la santé , à savoir le gradient social, condition de travail et l'exclusion sociale . Le test du chi - carré et de régression logistique multinomiale ont été appliquées. Résultat montrent que $50,7 \%$ avaient les 4 ou plusieurs visites prénatales recommandées ; $23,4 \%$ et $13,5 \%$ utilisent respectivement les établissements du secteur public et privé pour leur prestation la plus récente de l'enfant . Le risque relatif d'avoir 4 ou plusieurs visites prénatales à réduire par un facteur de 0,7863 pour les femmes musulmanes $(p<0,05)$, et une augmentation par un facteur de 5,3806 pour les femmes dans l'échelle sociale plus élevé $(p<0,01)$. La religion devrait être intégré dans les déterminants sociaux.

Mots-clés: Religion, maternelle, les soins de santé, l'utilisation, les femmes, déterminant social.

\section{Introduction}

The state of maternal health varies significantly within Nigeria. Major indices of maternal health and service utilisation such as antenatal care attendance, facility delivery, assistance during delivery, and postnatal check show disparity across the country particularly between the northern and southern regions. Studies have provided evidence that women who lived in Northern Nigeria were less likely to utilise health facility compared with their southern counterparts (Doctor, Bairagi, Findley, Helleringer \& Dahiru, 20II). This was corroborated by (Ononokpono and Odimegwu (2014) and National Population http://aps.journals.ac.za
Commission [NPC] and ICF International (2014) in the findings from the 2013 Nigeria Demographic and Health Survey (NDHS). They found among other variations that in the northeast zone, $41.0 \%$ of pregnant women received antenatal care from a skilled health provider compared with $90.6 \%$ in the southeast zone. Also in the southwest zone, $75 \%$ of most recent pregnancies were delivered in a health facility compared with II.5\% in the northwest zone.

As noted by Price, McKinney and Braun (20II), variation in health status or service utilisation may result both from biological differences or social disparities among different segments of the population. In Nigeria, while evidence is lacking on 
biological differences among the ethnic nationalities, it is evidently clear that substantial disparities exist on how societies within the Nigerian federation are structured and governed. These social disparities have continued to sustain maternal health inequities in the country. Global efforts aiming to address such inequities in maternal health across and within countries have led to the recognition of some factors as the social determinants of health. These factors refer to the basic determinants regarding whether individuals remain healthy or become ill (Mental Health America, 2013). The list of the social determinants include the social gradient; stress; early life development; social exclusion; work; unemployment; social support; addiction; food; and transport (World Health Organization [WHO], 2003).

However, the WHO list of social determinants of health may not be exhaustive as religion was not recognised as a social determinant of health contrary to several research findings that religion is a significant correlate of health care utilisation (Mekonnen \& Mekonnen, 2002; Benjamins, 2005; Gyimah, Takyi \& Addai, 2006; Benjamins, 2007) and improved health outcomes (McCullough, Hoyt, Larson, Koenig \& Thoresen, 2000; Musick, House \& Williams, 2004; Hebert, Dang \& Schulz, 2007). Research has further demonstrated that religion not only has profound effect on the health care beliefs and behaviours of people, but also the interpretation of religious teachings may influence utilisation of reproductive health care services (Testerman, 1997; Maguranyanga, 20II; United Nations Development Programme [UNDP], 20I I; Rumun, 20I4).

Although studies abound on the relationship between religious affiliation and different aspects of reproductive health issues such as child health (Chiswick and Mirtcheva, 2010); mental health (Herbert et al. 2007); adolescent sexual behaviour (Odimegwu, 2005); maternal health care (Gyimah et al. 2006); access to health care (Gillum, Jarrett \& Obisesan, 2009); and contraceptive use (Jones \& Dreweke, 20II; Farrell, Masquelier, Tissot \& Bertrand, 2014; Walelign, Mekonen, Netsere and Tarekegn, 2014), however, studies have rarely examine the need to integrate religion into the social determinants of health framework. The objective of the study is therefore to compare the influence of religion and selected social determinants of health on utilisation of maternal health care services. This is with the view to encouraging the integration of religion into the social determinants of health framework.

\section{Literature Review and Theoretical Framework}

Schiller and Levin (1988) noted that there is some level of religious factor in health care utilisation. Studies have consistently maintained that religion is associated with health care utilisation and improved health outcomes (Gyimah et al. 2006; Hebert et al. 2007; Chiswick \& Mirtcheva, 2010). Religion is thus one of the outstanding social institutions that shape individual and community health behaviour through its influence on lifestyles, worldviews and motivations (Benjamins, 2005). However, different religious groups have different views on health care and health issues. For instance, Maguranyanga (20l I) found that among the ultra-conservative Apostolic groups in Zimbabwe, religious teachings, doctrine and regulations of the group stressed faith healing and total adherence to church beliefs and practices that sometimes hinder modern healthcare seeking. The Jehovah's Witnesses, another Christian group encourages members not to accept transfusion of whole blood, red blood cells, white blood cells, platelets, and plasma based on the belief that certain Biblical passages prohibit blood transfusion (Loma Linda University, 2014). The group however does not object to the use of medical alternatives to blood transfusion.

Several other Christian groups particularly the contemporary Pentecostal groups have liberal health related teachings and doctrines (Oyedepo, 1995). However most of them are of the view that seeking spiritual counsel and faith healing should precede use of medications. This is link to the belief that health problems are caused by the influence of bad diet, natural phenomenon, wrath of God as a punishment for sin, demon possession, life style and malicious spiritual manipulations by enemies (Olanisebe, 2002; lkorok, 2003). Moslems also believe in the spiritual causes of health problems and often distinguish between illness that may be treated medically and those that may be related to the will of God (Padela \& Curlin, 20I2). Spiritualising health situation in the process of determining when to seek medical help or when to apply formal medicine shaped utilisation of health care by adherents of different religions. This is similar to the health belief of adherents of traditional religion. For instance, Odebiyi (1989 cited in Gazali, Muktar \& Gana, 20I2) found that among rural residents of lle-lfe in Southwestern Nigeria, most illnesses are first treated traditionally before seeking modern health care services.

The unacceptably high rate of child deliveries outside health facility in most parts of Nigeria could be attributed to seeking traditional help before patronising formal health care delivery system (Ojua, Ishor \& Ndom, 20I3). Given the pervasive belief in supernatural powers as explanation to individual http://aps.journals.ac.za 
health situations, it is surprising to observe that religion has not been extensively used to promote utilisation of maternal health care services in the country. The current National Population Policy for Sustainable Development being implemented in the country though recognised collaboration with religious organisations in the policy implementation, but rather than devise a religion-friendly programme that could be used to address the prevailing poor level of maternal health in the country, it only encouraged religious organisations to promote reproductive health services in line with their religious belief (NPopC, 2004).

The theoretical framework for the study is based on the functionalist perspective. Functionalism developed by Emile Durkheim (1858-1917), and refined by Talcott Parsons (1902-1979), examine religion from the viewpoint of societal needs. Durkheim discussed in Haralambos, Holborn and Heald (2004) categorised human society into "sacred" and "profane" worlds. The sacred involves the feeling of awe, fear and reverence that control the profane (everyday life including actions and behaviour). Religion as an integral part of the sacred is thus a means of controlling human action and behaviour. Durkheim further asserted that for human society to recreate itself or made steady progress, certain basic conditions such as social cooperation, order and control are crucial ingredients for which religion make critical contributions to their fulfilment.

Modifications to Durkheim's postulation by others such as Malinowski (1954) and Parsons (1965) buttressed the positive contributions of religion to human society. Parsons added that religion being part of the cultural system provides two basic things. On the one hand, it provides general rule for human behaviour. On the other hand, it provides criteria for the evaluation of human conduct. Though functionalist analysis remain useful in providing understanding of how social structure influence human behaviour, it is however weakened by its inability to account for the abnormal operations of religion such as the Boko Haram insurgency in Northern Nigeria and the sustained conflict between Sunni and Shiite Muslims in the Middle East.

Contrary to the functionalist's perspective, Marxists believe the social system that created religion will vanish with the emergence of communism, thereby ensuring non existence of religion in the management of human affairs under the communist state. Marx and Lenin described religious beliefs as tools of fostering class ideology and easing the pain of the oppressed for which religion serve as an instrument (Haralambos et al. 2004). By soliciting veneration for the ruling class and encouraging the acceptance of the status quo, religion serve as a means of social control by removing thoughts of revolutionary overthrow of the ruling class from the minds of the oppressed and giving them false hope in their deprived conditions.

Religion in the African continent despite its shortcomings has been fully involved in efforts to change society for good. With respect to health care, both Christianity and Islam have shown tremendous support for positive health outcomes. In Nigeria, there are countless numbers of faith-based health institutions providing health services in both urban and rural areas of the country. In addition, religious bodies have often aligned themselves with public health initiatives during major health crisis. For instance, in the wake of the Ebola pandemic in Nigeria, the Catholic Diocese of Markudi, North Central Nigeria promptly banned the lying of corpses in church auditorium in the areas under its jurisdiction so as to reduce exposure to risk of infection. Some other Pentecostal churches also banned handshaking during church services to prevent the spread of the contagious disease. However, little has so far been accomplished in the use of religion to boost utilisation of maternal health care services in the country.

\section{Data and Methods}

\section{Data Source}

Relevant data on maternal health among women were extracted from the 2013 NDHS. A total of 38,948 women were included in the survey. However, we analysed weighted sample of 19,087 women due to exclusion of some women such as those who have not had a live birth at all, those who have not had a live birth in the last five years preceding the survey, and women not currently married. The data were accessed online through MEASURE DHS website (www.measuredhs.com) sequel to the submission of abstract detailing the study objective and methodology.

\section{Research Variables}

The outcome variable in the study is utilisation of maternal health care services. This was measured using antenatal care and place of delivery. Antenatal care was measured by the number of antenatal care visits during the most recent pregnancy. We categorised antenatal visits into: no visit (I); I to 3 visits (2); and 4 or more visits (3) to reflect WHO recommendations that pregnant women visits health facility for antenatal care at least four times before delivery. Place of delivery was categorised into: public sector facility (I); private sector facility (2) and home or elsewhere. These grouping is justified 
because they represent the three dominant place of delivery reported in the 2013 NDHS (NPC and ICF International, 2014). The explanatory variables were religious affiliation and three purposively selected factors from the WHO lists of social determinants of health, namely the social gradient, work condition and social exclusion. These variables were selected because they could be generated from the NDHS data.

Social gradient was generated from the combination of education and household wealth to reflect the extent of the difference in wealth and opportunity between those with the most and those with the average or least social opportunity. The 'lower ladder' of the social gradient describes the proportion of respondents with the least socioeconomic opportunities. The 'middle ladder' describes the proportion with average opportunities, while the 'higher ladder' describes the proportion with adequate opportunities. Work condition was generated from the variable measuring occupation and categorised into three groups by the physical stress associated with the type of work. Less physically stressful work was defined as work entailing professional service or clerical work, while physically stressful work consists of agricultural, manual and other unskilled task.

Social exclusion measures the proportions of respondents prevented from full participation in household decisions. This was proxied by level of women's autonomy based on women's participation in decision about own health, visit to friends/relatives and purchase of household large items. Women who did not participate in the decisions were defined as having 'low autonomy' while women who participated jointly with male partner were defined as having 'moderate autonomy'. Women who participated solely were defined as having 'high autonomy'. The mediating variables were three identified problems in accessing health care. The problems were measured in the study by getting permission to go for treatment, getting money for treatment, and distance to health facility in line with DHS standard measurement (Vadnais, Kols \& Abderrahim, 2006). The problems were however combined to reflect whether they constitute problem to accessing health care or otherwise.

\section{Data Analysis}

The Stata was used to perform all statistical analysis. Frequency tables were used to describe sample characteristics, problem in accessing health care and maternal health care use. The bivariate analysis entails the use of chi-square statistic to examine the association or relationship among the research variables. At the multivariate level, the multinomial 1871 logistic regression was performed to further examine the relationship between the explanatory variables and utilisation of maternal health care services. However, the multinomial regression was performed separately for antenatal care and place of delivery.

The multinomial logistic regression is appropriate for analysis in the current study because both measures of the outcome variable in the study are categorised into three unordered categories (StatCorp, 2009; Bayaga, 2010). In the current study, the multinomial logistic regression was replicated in three models with I to 3 antenatal visits and private sector facility as base outcomes. Model $\mathrm{I}$ included only religious affiliation. Model 2 included religious affiliation and the selected social determinants of health. Model 3 included all the explanatory variables; the mediating variable as well as few background variables. The background variables included are region, age and place of residence. These variables have been found to associate with maternal health care use in previous studies (Doctor et al. 20II; Ononokpono and Odimegwu, 20l4). The relative risk ratios (rrr) are used in the study to report the estimated coefficients of the multinomial model. This measures the risk of no antenatal visit or 4 or more visits with respect to antenatal care and the risk of public sector facility delivery or home/elsewhere delivery with respect to place of delivery.

\section{Data limitations}

In understanding the inferences made in the study, it is necessary to borne in mind that religion as measured in the NDHS measures only religious affiliation and not individual religiosity. We are not able to assess individual commitment to religious organisations or their exposure/commitment to religious health teachings which may exert more influence on health utilisation than religious affiliation. In addition, the NDHS did not provide information on major groups within the Christian faith. Denominations such as Apostolic Faith, Baptist, Anglican Communion and new generation Christian groups were all classified as 'Other Christians'. This did not permit analysis by Christian denominations. Data describing complete set of social determinants of health are not available in the NDHS. Hence, we could not examine the full framework of the social determinants of health approach. We used physical stress to denote work condition. However, in reality, stress is a mental or psychological condition which physical stress may not accurately approximate. We excluded women who reported practising traditional or other religion because their proportion among the respondents was insignificant. 


\section{Results}

\section{Profile of Respondents}

Table I present results of selected characteristics of the respondents and problem in accessing health care. Moslem women were dominant in the sample. More than half of the women are in the lower social ladder. Slight more than one-third of the women are however in the middle social ladder. The proportion of the women in the higher social ladder is less than one-tenth. Less than one-third of the women are unemployed. Among the respondents, the work condition of majority of them is physically stressful. Only less than one-tenth of them have less physically stressful work condition. More than half of the respondents have low autonomy. However, more than one-third of the women have moderate autonomy while less than one-tenth have high autonomy. Wealth distribution is nearly equal among the women. Though, the highest proportions of the women are either in the 'poorest' or 'poorer' wealth groups, the same proportions of the women are in the 'richer' and 'richest' wealth groups. Women from the three northern geo-political zones are dominant in the sample. Nearly two-thirds of the respondents reside in rural areas of the country compared with the slightly above one-third that reside in urban areas of the country. The dominant age groups in the sample are age groups 25-29 years and 30-34 years with each age groups representing more than onefifth of the total sample. Majority of the women do not have any problem accessing health care. 
Table I: Distribution of respondents by selected socio-demographic characteristics, social determinants of health and problem accessing health care, Nigeria 2013

\begin{tabular}{|c|c|c|}
\hline Variable & Number of women & Percent \\
\hline \multicolumn{3}{|l|}{ Religion: } \\
\hline \multicolumn{3}{|l|}{ Religious affiliation } \\
\hline Christianity & 6,911 & 36.2 \\
\hline Islam & 12,176 & 63.8 \\
\hline \multicolumn{3}{|l|}{ Social Determinants: } \\
\hline \multicolumn{3}{|l|}{ The social gradient } \\
\hline Lower Ladder & 11,160 & 58.5 \\
\hline Middle Ladder & 6,771 & 35.5 \\
\hline Higher Ladder & 1,156 & 6.0 \\
\hline \multicolumn{3}{|l|}{ Work condition } \\
\hline No work & 5,633 & 29.5 \\
\hline Physically stressful & 11,815 & 61.9 \\
\hline Less physically stressful & 1,639 & 8.6 \\
\hline \multicolumn{3}{|l|}{ Women autonomy } \\
\hline Low & 9,612 & 50.4 \\
\hline Moderate & 7,393 & 38.7 \\
\hline High & 2,082 & 10.9 \\
\hline \multicolumn{3}{|l|}{ Socio-demographic } \\
\hline \multicolumn{3}{|l|}{ Wealth index } \\
\hline Poorest & 4,507 & 23.6 \\
\hline Poorer & 4,267 & 22.4 \\
\hline Middle & 3,481 & 18.2 \\
\hline Richer & 3,415 & 17.9 \\
\hline Richest & 3,417 & 17.9 \\
\hline \multicolumn{3}{|l|}{ Region } \\
\hline North-central & 2,675 & 14.0 \\
\hline North-east & 3,275 & 17.2 \\
\hline North-west & 7,182 & 37.6 \\
\hline South-east & $\mathrm{I}, 467$ & 7.7 \\
\hline South-south & 1,694 & 8.9 \\
\hline South-west & 2,794 & 14.6 \\
\hline \multicolumn{3}{|l|}{ Place of residence } \\
\hline Urban & 6,759 & 35.4 \\
\hline Rural & 12,328 & 64.6 \\
\hline \multicolumn{3}{|l|}{ Age } \\
\hline $15-19$ & 1,138 & 6.0 \\
\hline $20-24$ & 3,639 & 19.1 \\
\hline $25-29$ & 5,065 & 26.5 \\
\hline $30-34$ & 4,049 & 21.2 \\
\hline $35-39$ & 3,012 & 15.8 \\
\hline $40-44$ & $\mathrm{I}, 552$ & 8.1 \\
\hline $45-49$ & 632 & 3.3 \\
\hline \multicolumn{3}{|c|}{ Problem accessing health care } \\
\hline At least one problem & $\mathrm{I}, 572$ & 8.2 \\
\hline No problem & 17,515 & 91.8 \\
\hline Total & 19,087 & 100.0 \\
\hline
\end{tabular}

Source: $2013 \mathrm{NDHS}$ 


\section{Utilisation of Maternal Health Care Services}

Table 2 presents result of respondents' utilisation of maternal health care services. As shown in the table, more than one-third of the women had no antenatal visit during their most recent pregnancy. Slightly more than one-tenth of the women had I-3 antenatal visits, while slightly more-than half of them had the recommended 4 or more antenatal visits during their most recent pregnancies. The dominant place of delivery is respondent's home or elsewhere with nearly two-third having had the most recent delivery outside formal health facility. However, more than one-third of the respondents utilised health facility for their most recent child delivery. Among those who utilised health facility, majority utilised public sector health facility.

Table 2: Utilisation of Maternal Health Care Services, Nigeria, 2013

\begin{tabular}{lcc}
\hline Outcome variable & Number of women & Percent \\
\hline Number of antenata/ visit & 7,102 & \\
No antenatal visit & 2,316 & 37.2 \\
I-3 visits & 9,669 & 12.1 \\
4 or more visits & & 50.7 \\
Place of delivery & 4,469 & \\
Public sector facility & 2,574 & 23.4 \\
Private sector facility & 12,044 & 13.5 \\
Home or elsewhere & 19,087 & 63.1 \\
Total & & 100.0 \\
\hline
\end{tabular}

Source: $2013 \mathrm{NDHS}$

\section{Correlates of Utilisation of Maternal Health Care Services}

The relationship between explanatory and mediating variables and maternal health care use is presented in Table 3. Religious affiliation is associated with maternal health care use. Christian women had 4 or more antenatal visits than their Muslim counterparts. More Christian women also utilised facility delivery than Muslim women. The chi-square statistic indicates significant association between religious affiliation and antenatal care $\left(\chi^{2}=193.5, p<0.05\right)$ and place of delivery $\left(\chi^{2}=347.8, p<0.05\right)$. Women at the lower level of the social ladder have poor utilisation of both antenatal care and facility delivery. As individual women's position improves on the social ladder from low to middle, and from middle to higher ladder, utilisation of 4 or more antenatal visits improves while the proportion of home/elsewhere deliveries reduces among them. The chi-square test confirms the significant association between the social gradient and antenatal care $\left(\chi^{2}=388.6, p<0.05\right)$ and place of delivery $\left(\chi^{2}=457.2, p<0.05\right)$.

Work condition also show significant association with antenatal care $\left(\chi^{2}=86.1, p<0.05\right)$ and place of delivery $\left(\chi^{2}=129.6, p<0.05\right)$. However, women with no work were worst off with respect to antenatal visits compared with their counterparts either with physically stressful work or less stressful work. Women with no work also had the highest proportions of home deliveries. Women autonomy also significantly associates with antenatal care $\left(\chi^{2}=130.6, p<0.05\right)$ and place of delivery $\left(\chi^{2}=233.3, p<0.05\right)$. Women with low autonomy have the highest proportion of no antenatal visit as well as the least proportion of the recommended 4 or more antenatal visits. They also have the highest proportion of home deliveries.

Region of residence show significant association with utilisation of maternal health care services. The three northern zones particularly the north-east and north-west zones had the least proportion of the recommended 4 or more antenatal visits while the three southern zones fared significantly better in the recommended antenatal visits. The north-east and north-west zones also had the poorest level of health facility deliveries. Other variables analysed such as age, problem accessing health care and place of residence also significantly associates with maternal health care use. For instance, rural women had the lower proportion of the recommended antenatal visits compared with urban women. Overall, it is worthy of note that religious affiliation and the selected social determinants of health have similar associations with utilisation of maternal health care services. These relationships were further investigated in the multivariate analysis. 
Table 3: Cross tabulations of utilisation of health care services with explanatory and mediating variables

\begin{tabular}{|c|c|c|c|c|c|c|}
\hline \multirow[b]{2}{*}{ Variable } & \multicolumn{3}{|c|}{ Antenatal care } & \multicolumn{3}{|c|}{ Place of Delivery } \\
\hline & No visit & I-3 visits & $4+$ visits & $\begin{array}{l}\text { Public } \\
\text { facility }\end{array}$ & $\begin{array}{l}\text { Private } \\
\text { facility }\end{array}$ & $\begin{array}{l}\text { Home/ } \\
\text { elsewhere }\end{array}$ \\
\hline \multicolumn{7}{|l|}{ Religious affiliation } \\
\hline Christianity & 18.3 & 9.6 & 72.1 & 35.9 & 28.5 & 35.6 \\
\hline Islam & 47.9 & 13.6 & 38.5 & 16.4 & 4.9 & 78.7 \\
\hline Statistic & \multicolumn{3}{|c|}{$\mathrm{Df}=2, \quad \mathrm{X}^{2}=193.5, \mathrm{p}<0.05$} & \multicolumn{3}{|c|}{$D f=2, x^{2}=347.8, p<0.05$} \\
\hline \multicolumn{7}{|l|}{ The social gradient } \\
\hline Lower ladder & 55.1 & 14.1 & 30.8 & 11.6 & 3.2 & 85.2 \\
\hline Middle ladder & 13.2 & 10.1 & 76.7 & 38.0 & 25.7 & 36.3 \\
\hline Higher ladder & 5.9 & 4.9 & 89.2 & 51.8 & 41.4 & 6.8 \\
\hline Statistic & \multicolumn{3}{|c|}{$\mathrm{Df}=4, \quad \mathrm{x}^{2}=388.6, \mathrm{p}<0.05$} & \multicolumn{3}{|c|}{$D f=4, x^{2}=457.2, p<0.05$} \\
\hline \multicolumn{7}{|l|}{ Work condition } \\
\hline No work & 48.5 & 12.6 & 38.9 & 17.6 & 8.4 & 74.0 \\
\hline Physically stressful & 35.1 & 12.6 & 52.3 & 23.5 & 13.5 & 63.0 \\
\hline Less physically stressful & 13.5 & 7.6 & 78.9 & 42.3 & 31.1 & 26.6 \\
\hline Statistic & \multicolumn{3}{|c|}{$D f=4, x^{2}=86.1, p<0.05$} & \multicolumn{3}{|c|}{$D f=4, X^{2}=129.6, p<0.05$} \\
\hline \multicolumn{7}{|l|}{ Women autonomy } \\
\hline Low & 48.6 & 14.6 & 36.8 & 16.0 & 4.2 & 79.8 \\
\hline Moderate & 27.8 & 9.6 & 62.6 & 29.5 & 21.6 & 48.9 \\
\hline High & 17.9 & 9.6 & 72.5 & 35.7 & 27.7 & 36.6 \\
\hline Statistic & \multicolumn{3}{|c|}{$D f=4, x^{2}=130.6, p<0.05$} & \multicolumn{3}{|c|}{$D f=4, x^{2}=233.3, p<0.05$} \\
\hline \multicolumn{7}{|l|}{ Region } \\
\hline North-central & 27.0 & 16.2 & 56.8 & 32.0 & 15.8 & 52.2 \\
\hline North-east & 43.7 & 17.7 & 38.6 & 18.9 & 1.3 & 79.8 \\
\hline North-west & 56.8 & 13.1 & 30.1 & 12.2 & 0.5 & 87.3 \\
\hline South-east & 8.4 & 7.5 & 84.1 & 33.0 & 47.5 & 19.5 \\
\hline South-south & 29.3 & 8.2 & 62.5 & 36.7 & 15.4 & 47.9 \\
\hline South-west & 9.0 & 4.0 & 87.0 & 36.2 & 39.9 & 23.9 \\
\hline Statistic & \multicolumn{3}{|c|}{$D f=10, x^{2}=59.3, p<0.05$} & \multicolumn{3}{|c|}{$D f=10, x^{2}=107.2, p<0.05$} \\
\hline \multicolumn{7}{|l|}{ Age } \\
\hline $15-19$ & 51.2 & 15.1 & 33.7 & 17.8 & 3.9 & 78.3 \\
\hline $20-24$ & 39.8 & 14.1 & 46.1 & 21.4 & 10.7 & 67.9 \\
\hline $25-29$ & 35.8 & 12.6 & 51.6 & 24.2 & 14.3 & 61.5 \\
\hline $30-34$ & 33.4 & 10.4 & 56.2 & 25.0 & 16.7 & 58.3 \\
\hline $35-39$ & 34.0 & 10.7 & 55.3 & 25.7 & 15.6 & 58.7 \\
\hline $40-44$ & 38.6 & 10.2 & 51.2 & 23.1 & 13.9 & 63.0 \\
\hline $45-49$ & 44.3 & 13.9 & 41.8 & 18.9 & 8.0 & 73.1 \\
\hline Statistic & \multicolumn{3}{|c|}{$D f=12, x^{2}=14.5, p<0.05$} & \multicolumn{3}{|c|}{$D f=12, x^{2}=282.9, p<0.05$} \\
\hline \multicolumn{7}{|l|}{ Place of residence } \\
\hline Urban & 14.8 & 10.8 & 74.4 & 36.5 & 26.8 & 36.7 \\
\hline Rural & 49.4 & 12.9 & 37.7 & 16.2 & 6.2 & 77.6 \\
\hline Statistic & \multicolumn{3}{|c|}{$D f=2, x^{2}=156.1, p<0.05$} & $D f=2$, & 164.9, p & \\
\hline Problem accessing healt & & & & & & \\
\hline At least one problem & 70.9 & 8.7 & 20.4 & 8.3 & 3.3 & 88.4 \\
\hline No problem & 34.2 & 12.4 & 53.4 & 24.8 & 14.4 & 60.8 \\
\hline Statistic & $\mathrm{Df}=$ & $=187.8$ & .05 & $\mathrm{Df}=2$ & 149.9, p & \\
\hline
\end{tabular}




\section{Multivariate analyses}

Table 4 presents result of the influence of the explanatory variables on antenatal care use. In Model $\mathrm{I}$, the relative risk of being in 4 or more antenatal visits category instead of $\mathrm{I}-3$ antenatal visits will reduce by a factor of 0.3787 for Muslim women compared to Christian women $(\mathrm{p}<0.0 \mathrm{I})$. Likewise, the relative risk of being in no antenatal visit category instead of $\mathrm{I}-3$ antenatal visit category will increase by a factor of 1.8562 for Muslim women compared to Christian women $(p<0.01)$. The inclusion of the social determinants of health in Model 2 slightly alters the nature of the relationship between religious affiliation and antenatal care utilisation. In the model, the relative risk of being in 4 or more antenatal visits category instead of I-3 antenatal visits will reduce by a factor of 0.7863 for Muslim women compared to Christian women $(p<0.05)$. Though, the relative risk of being in no antenatal visit category instead of $\mathrm{I}-3$ antenatal visit category will increase by a factor of I.2588 for Muslim women compared to Christian women. These influence is however not statistically significant.

Only the social gradient show consistent influence on antenatal care use among the selected social determinants of health. On the one hand, the relative risk of being in 4 or more antenatal visits category instead of I-3 antenatal visits will increase by a factor of 2.5909 for women in the middle social ladder compared to women in the lower social ladder $(p<0.0 \mathrm{I})$. Likewise, the relative risk of being in 4 or more antenatal visits category instead of I-3 antenatal visits will increase by a factor of 5.3806 for women in the higher social ladder compared to women in the lower social ladder $(p<0.0 \mathrm{l})$. On the other hand, the relative risk of being in no antenatal visit category instead of I-3 antenatal visit category will reduce by a factor of 0.3607 for women in the middle social ladder and by 0.3285 for women in the higher social ladder compared to women in the reference category. Other social determinants of health analysed reveal inconsistent influence on antenatal care use.

In Model 3, the social gradient remains a consistent predictor of antenatal care use compared to other selected social determinants of health as well as other variables included in the model. The relative risk of being in 4 or more antenatal visits category instead of I-3 antenatal visits will increase by a factor of 1.8648 for women in the middle social ladder compared to women in the lower social ladder $(p<0.01)$. Likewise, the relative risk of being in 4 or more antenatal visits category instead of $\mathrm{I}-3$ antenatal visits will increase by a factor of $3.5 \mathrm{I} 23$ for women in the higher social ladder compared to women in the lower social ladder $(p<0.0 \mathrm{l})$. Other variables maintain inconsistent influence on antenatal care use. 
Table 4: Multinomial logistic regression showing relative risk ratio of 4 or more antenatal visits and no antenatal visit with I-3 antenatal visits as base outcome

\begin{tabular}{|c|c|c|c|c|c|c|}
\hline \multirow[b]{2}{*}{ Variable } & \multicolumn{2}{|c|}{4 or more antenatal visits } & \multicolumn{4}{|c|}{ No antenatal visit } \\
\hline & Model I & Model 2 & Model 3 & Model I & Model 2 & Model 3 \\
\hline & $\mathrm{rrr}$ & rrr & rrr & $\mathrm{rrr}$ & rrr & $\mathrm{rrr}$ \\
\hline \multicolumn{7}{|l|}{ Religious affiliation } \\
\hline Christianity (Ref) & - & - & - & - & - & - \\
\hline Islam & $0.3786 *$ & $0.7863^{* *}$ & $1.0552^{* * * *}$ & $\mathrm{I} .8562 *$ & I. $2588 * * *$ & I.4338** \\
\hline \multicolumn{7}{|l|}{ The Social gradient } \\
\hline Lower ladder (Ref) & - & - & - & - & - & - \\
\hline Middle ladder & - & $2.5909 *$ & 1.8648* & - & $0.3607 *$ & $0.4012 *$ \\
\hline Higher ladder & - & $5.3806 *$ & $3.5123 *$ & - & $0.3285 *$ & $0.4193 * * *$ \\
\hline \multicolumn{7}{|l|}{ Work condition } \\
\hline No work (Ref) & - & - & - & - & - & - \\
\hline Stressful & - & I.1266*** & $0.9794 * * *$ & - & $0.76 \mid 4^{* *}$ & $0.6953^{*}$ \\
\hline Less stressful & & I.3577** & $1.1133 * * *$ & - & $0.7628 * * *$ & $0.6897 * *$ \\
\hline \multicolumn{7}{|l|}{ Women autonomy } \\
\hline Low (Ref) & - & - & - & - & - & - \\
\hline Moderate & - & $0.6276 *$ & $0.7612 *$ & - & $0.8113^{* *}$ & $0.7889 * *$ \\
\hline High & - & $1.0100 * * *$ & $0.8287^{* * * *}$ & - & $0.8213^{* * *}$ & $0.8260 * * *$ \\
\hline \multicolumn{7}{|l|}{ Region } \\
\hline North-central (Ref) & - & - & - & - & - & - \\
\hline North-east & - & - & $0.7278^{* *}$ & - & - & $0.9850 * * *$ \\
\hline North-west & - & - & $0.7978 * * *$ & - & - & $1.8193 * *$ \\
\hline South-east & - & - & 2.3073* & - & - & $1.4532 * * *$ \\
\hline South-south & - & - & $\mathrm{I} .4697^{* *}$ & - & - & $4.1299 *$ \\
\hline South-west & - & - & 4.0079* & - & - & $2.3566 * *$ \\
\hline \multicolumn{7}{|l|}{ Age } \\
\hline $15-19$ (Ref) & - & - & - & - & - & - \\
\hline $20-24$ & - & - & $1.1253^{* * * *}$ & - & - & $0.9922 * * *$ \\
\hline $25-29$ & - & - & I.I597**** & - & - & I.0740*** \\
\hline $30-34$ & - & - & $1.4206^{* * * *}$ & - & - & I.267I $* * *$ \\
\hline $35-39$ & - & - & $1.4166^{* * *}$ & - & - & I.2356*** \\
\hline $40-44$ & - & - & $\mathrm{I} .4883^{* * *}$ & - & - & I.3925** \\
\hline $45-49$ & - & - & I.1043*** & - & - & $1.1194 * * *$ \\
\hline \multicolumn{7}{|l|}{ Place of residence- } \\
\hline Urban (Ref) & - & - & - & - & - & - \\
\hline Rural & - & - & $0.8780^{* * * *}$ & - & - & $2.1162 *$ \\
\hline \multicolumn{7}{|c|}{ Problem accessing health care } \\
\hline At least one problem (Ref) & - & - & - & - & - & - \\
\hline No problem & - & - & $1.2839 * * *$ & - & - & $0.4322 *$ \\
\hline
\end{tabular}

Notes: ${ }^{*} p<0.01 ;{ }^{* *} p<0.05 ;{ }^{* * *} \mathrm{p}>0.05 ;$ Ref $=$ reference category

Table 5 presents result of the influence of the explanatory variables on place of delivery. In Model I, the relative risk of being in delivery in public sector facility category instead of delivery in private sector facility will increase by a factor of 2.6329 for Muslim women compared to Christian women $(p<0.01)$. Likewise, the relative risk of being in delivery at home or elsewhere category instead of delivery in private sector facility will increase by a factor of 12.754 I for Muslim women compared to Christian women $(p<0.01)$. The inclusion of the social 1877 determinants of health in Model 2 did not alter the nature of the relationship between religious affiliation and place of delivery. In the model, the relative risk of being in delivery in public sector facility category instead of delivery in private sector facility will increase by a factor of 1.8476 for Muslim women compared to Christian women $(p<0.01)$. Likewise, the relative risk of being in delivery at home or elsewhere category instead of delivery in private sector facility will increase by a factor of 3.509 I for

http://aps.journals.ac.za 
Muslim women compared to Christian women $(\mathrm{p}<0.0 \mathrm{I})$.

With the exclusion of work condition, the selected social determinants of health have significant influence on place of delivery. For instance, the relative risk of being in delivery in public sector facility category instead of delivery in private sector facility consistently reduces as women's position on the social ladder improves from middle to higher. Likewise, the relative risk of being in delivery in public sector facility category instead of delivery in private sector facility will increase by a factor of 2.0034 for women with moderate autonomy compared to women in the reference category $(\mathrm{p}<0.0 \mathrm{I})$ while the relative risk of being in delivery in public sector facility category instead of delivery in private sector facility will reduce by a factor of 0.9637 for women with high autonomy compared to women in the reference category $(\mathrm{p}<0.0 \mathrm{I})$. Thus, suggesting that women with high autonomy may patronise private sector facility than public sector facility. In Model 3, religious affiliation, the social gradient, region, place of residence and problem to accessing health care were the significant predictors of maternal health care use.

Table 5: Multinomial logistic regression showing relative risk ratio of delivery in public sector facility and delivery at home/elsewhere with delivery in private sector as base outcome

\begin{tabular}{|c|c|c|c|c|c|c|}
\hline \multirow[b]{2}{*}{ Variable } & \multicolumn{3}{|c|}{ Delivery in public sector facility } & \multicolumn{3}{|c|}{ Delivery at home or elsewhere } \\
\hline & $\begin{array}{c}\text { Model I } \\
\text { rrr }\end{array}$ & $\begin{array}{c}\text { Model } 2 \\
\text { rrr }\end{array}$ & $\begin{array}{c}\text { Model } 3 \\
\text { rrr }\end{array}$ & $\begin{array}{c}\text { Model I } \\
\text { rrr }\end{array}$ & $\begin{array}{c}\text { Model } 2 \\
\text { rrr }\end{array}$ & $\begin{array}{c}\text { Model } 3 \\
\text { rrr }\end{array}$ \\
\hline \multicolumn{7}{|l|}{ Religious affiliation } \\
\hline Christianity (Ref) & - & - & - & - & - & - \\
\hline Islam & 2.6329* & $1.8476 *$ & 2.0786* & $|2.754|^{*}$ & $3.509 I^{*}$ & $|.222| * * *$ \\
\hline \multicolumn{7}{|l|}{ The Social gradient } \\
\hline Lower ladder (Ref) & - & - & - & - & - & - \\
\hline Middle ladder & - & $0.6214 *$ & $0.2858 *$ & - & $0.1236 *$ & $0.9708 * * *$ \\
\hline Higher ladder & - & $0.5503 *$ & $0.0446 *$ & - & $0.0175 *$ & $0.8429 * * *$ \\
\hline \multicolumn{7}{|l|}{ Work condition } \\
\hline No work (Ref) & - & - & - & - & - & - \\
\hline Stressful & - & $0.9897 * * *$ & $1.0563 * * *$ & - & $0.8103^{* *}$ & I.2018** \\
\hline Less stressful & & $1.0104 * * *$ & $0.8834 * * *$ & - & $0.6196 * *$ & $|.252| * *$ \\
\hline \multicolumn{7}{|l|}{ Women autonomy } \\
\hline Low (Ref) & - & - & - & - & - & - \\
\hline Moderate & - & $2.0034 *$ & 1.7792* & - & $2.8189 *$ & $1.44 \mid 2 * *$ \\
\hline High & - & $0.9637 * * *$ & $1.1125 * * *$ & - & $0.7832 * *$ & I.1259*** \\
\hline \multicolumn{7}{|l|}{ Region } \\
\hline North-central (Ref) & - & - & - & - & - & - \\
\hline North-east & - & - & $12.123 \mid *$ & - & - & $7.0578 *$ \\
\hline North-west & - & - & $30.3012^{*}$ & - & - & $10.8052 *$ \\
\hline South-east & - & - & $0.4547 * *$ & - & - & $0.4357^{*}$ \\
\hline South-south & - & - & $3.3694 *$ & - & - & $1.4592 * *$ \\
\hline South-west & - & - & $0.6054 * *$ & - & - & $0.5663 * *$ \\
\hline \multicolumn{7}{|l|}{ Age } \\
\hline $15-19$ (Ref) & - & - & - & & - & - \\
\hline $20-24$ & - & - & $0.6819 * * *$ & & - & $0.583 I^{* *}$ \\
\hline $25-29$ & - & - & $0.8017 * * *$ & & - & $0.6501 * *$ \\
\hline $30-34$ & - & - & $0.804 I^{* * * *}$ & & - & $0.6140 * *$ \\
\hline $35-39$ & - & - & $0.7679 * * *$ & & - & $0.6558^{* *}$ \\
\hline $40-44$ & - & - & $0.7739 * * *$ & & - & $0.6474 * *$ \\
\hline $45-49$ & - & - & $1.0101 * * *$ & & - & $0.7866 * * *$ \\
\hline \multicolumn{7}{|l|}{ Place of residence- } \\
\hline Urban (Ref) & - & - & - & & - & - \\
\hline Rural & - & - & 2.8984* & & - & $1.3123 * *$ \\
\hline \multicolumn{7}{|c|}{ Problem accessing health care } \\
\hline At least one problem (Ref) & - & - & - & - & - & - \\
\hline No problem & - & - & $0.4202 *$ & - & - & $0.8637 * * *$ \\
\hline
\end{tabular}

Notes: ${ }^{*} p<0.01 ;{ }^{*}{ }^{*} p<0.05 ;{ }^{* *} \mathrm{p}>0.05 ;$ Ref $=$ reference category 


\section{Discussion}

We used a nationally representative sample to examine the relationship between religious affiliation and utilisation of maternal health care services. Four major findings emerged from our analysis. First, all the women sampled have religious affiliation similar to the extent of religious affiliation reported in previous studies (Benjamins, 2005; Gyimah et al. 2006; Jones \& Dreweke, 20II) and indicating that religion may be central to the life of all the women as suggested by functionalism. The affiliation of all the women to one religion or the other further suggests the possibility of exposure to religious beliefs or practices that could shape their reproductive health decision making and practices, and to that extent religion remain one of the potent tool that could be explored to boost utilisation of health services among them. Second, different levels of utilisation of maternal health care services were found among Christians and Muslim women. Muslim women have lower utilisation of maternal health care services. This is consistent with findings in previous studies such as Mekonnen and Mekonnen (2002), Gyimah et al. (2006) and Doctor et al. (20II). When utilisation was disaggregated by region, we found also that the three northern zones with a preponderance of Muslim women had lower utilisation of both antenatal care and facility delivery. The possibility of higher use of health care services by Christian women in Nigeria may not be unconnected with higher level of education usually found among women in southern Nigeria compared with women in Northern Nigeria who were preponderance in the current study. However, we found in the multivariate analysis that Muslim women utilise public sector facility than other women indicating that addressing health care utilisation among Muslim women may require immediate improvement in public sector facilities particularly in northern Nigeria.

Third, consistent with findings by Benjamins (2005), Gyimah et al. (2006), Benjamins (2007), Hebert et al. (2007), and Ononokpono and Odimegwu (2014), religious affiliation was found to be a significant correlate of maternal health care use. In addition we found that religious affiliation has similar influence on maternal health care use like some of the selected social determinants of health. Our finding tends to confirm the assertion by Schiller and Levin (1988) that there is a religious factor in health care utilisation. The religious factor in health care utilisation may be attributed to the social support women usually get by being members of religious groups. In several instances, religious groups particularly among Pentecostal Christian groups organise free medical counselling and treatment for members which may boost utilisation of health care 1879 by the members. The differentials in the utilisation of maternal health care found among Christians and Moslem women however does not infer lack of social support for Moslem women, but more likely to be connected to either insufficient number of health personnel providing such medical support within the Islamic group in Nigeria or to differences in the level of access to health care particularly in Northern Nigeria where the Purdah system may constraint a lot of women from moving freely outside their homes.

Fourth, multivariate analysis show that religious affiliation has similar significant influence on utilisation of maternal health care services when compared with the selected social determinants of health analysed in the study. Only the social gradient fared better than religious affiliation in predicting utilisation of maternal health care. This is an indication that the world must take a second look at religion if global health targets particularly those seeking improvement in maternal, newborn, and child health must be achieved in developing countries especially in sub Saharan Africa. Though religious groups may sometimes take extreme positions on some health issues, this is not sufficient to justify the exclusion of religion from the list of social determinants of health. Experience as shown that such extreme positions, are usually based on misconceptions rather than lack of support for health care. It is perhaps time for stakeholders in global maternal health advocacy not only to devise more concrete actions for countering conventional religious positions on health issues particularly maternal health care issues, but to also begin to assemble evidence showing that religious beliefs and utilisation of maternal health care services are not antithetical as found by Jones and Dreweke (20II).

Religion is central to life in many parts of Africa, therefore the positive virtues of religion should be optimally exploited to promote maternal health. Religious beliefs can cause several African women to ignore vital maternal health care services, refuse to be attended to by male health personnel, and prefer faith to quality medicine. More initiatives involving adequate sensitisation and mobilisation of religious organisations will not only improve maternal health outcomes, they will also contribute to clearing misconceptions surrounding some maternal health issues. In Nigeria where the state of maternal and child health is among the poorest in the world, more proactive measures involving religious organisations are required. The unprecedented rise in the number of religious sects built around the personality and charisma of the founder can be positively used for maternal health care promotion if religion-friendly public health programmes are design to mobilise and

http://aps.journals.ac.za 
educate religious leaders on maternal health issues. Such programme does not need to show preference for any particular religion, but should seek to aligned positive health beliefs and teachings of all religions with the need to improve maternal and child health in the country through better utilisation of health services.

\section{Conclusion}

This study assessed the relationship between religious affiliation and utilisation of maternal health care services as compared with the relationship between selected social determinants of health and maternal health care use in Nigeria. Religion has influence on utilisation of maternal health care services that is comparable with the influence of the selected social determinants of health. Neglecting religion and focusing on addressing the social determinants of health may not improve maternal health care utilisation in the country. Special attention must be paid to addressing health utilisation among Muslim women by taken more proactive steps to upgrade the availability of public sector health facility in the country. It is important to integrate religion into the social determinants of health framework.

\section{References}

Bayaga, A. (2010). "Multinomial Logistic Regression: Usage and Application in Risk Analysis". Journal of Applied Quantitative Methods 5(2): 288-297.

Benjamins, M. R. 2005. "Religious Influences on Preventive Health Care Use in a Nationally Representative Sample of Middled-Age Women". Journal of Behavioral Medicine DOI: 10.1007/s 10865-005-9035-2.

Benjamins, M. R. 2007. "Predictors of Preventive Health Care Use Among Middle-aged andOlder Adults in Mexico: The Role of Religion". Journal of Cross Cultural Gerontology 22:221-234.

Chiswick, B. R., and Mirtcheva, D. M. 2010. "Religion and Child Health". Discussion Paper No, 5215. Retrieved August 25, 2014 from ftp.iza.org/dp5215.pdf

Doctor, H. V., Bairagi, R., Findley, S. E., Helleringer, S., and Dahiru, T. 201I. "Northern Nigeria Maternal, Newborn and Child Health Programme: Selected Analyses from Population-Based Baseline Survey”. The Open Demography Journal 4:II-2I.

Farrell, M., Masquelier, A., Tissot, E., and Bertrand, J. 2014. "Islam, Polygyny and Modern Contraceptive Use in Francophone Sub-Saharan Africa". African Population Studies, 28(3): I 389-1398

Gazali, W. A., Muktar. F., and Gana, M. M. 2012. "Barriers to Utilisation of Maternal Health Care Facilities among Pregnant and Non-Pregnant Women of Child Bearing Age in Maiduguri http://aps.journals.ac.za
Metropolitan Council (MMC) and Jere LGAS of Borno State". Continental Journal of Tropical Medicine 6(I): I2-2I.

Gillum, R. F., Jarrett, N., and Obisesan, T. O. 2009. "Access to Health Care and Religion among Young American Men". International Journal of Environmental Research and Public Health 6:3225-3234.

Gyimah, S. O., Takyi, B. K., and Addai, I. 2006. "Challenges to the reproductive-health needs of African women: On religion and maternal health utilization in Ghana". Social Science \& Medicine 62:2930-2944.

Haralambos, M., Holborn, M., and Heald, R. 2004. Haralambos and Holborn Sociology: Themes and Perspectives (Sixth edition). London: HarperCollins Publishers Limited

Hebert, R. S., Dang, Q., and Schulz, R. 2007. "Religious Beliefs and Practices are Associated with Better Mental Health in Family Caregivers of Patients with Dementia: Findings from the REACH Study". American Journal of Geriatric Psychiatry I5(4):292-300.

lkorok, M. M.2003. "Christian Religious Practices and Their Influence on Health" in P.Ade Dopamu et al. (eds) African Culture, Modern Science and Religious Thought, Ilorin, African Centre for Religions and the Sciences, pp. 518-527.

Jones, R. K., and Dreweke, J. 20II. Countering Conventional Wisdom: New Evidence on Religion and Contraceptive Use. New York: Guttmacher Institute

Loma Linda University. 2014. "Health Care and Religious Beliefs". Retrieved July 2, 2014 from http://lomalindahealth.org/..healthcare-religiousbeliefs.pdf

Maguranyanga, B. 20II. Apostolic Religion, Health and Utilization of Maternal and Child Health in Zimbabwe. Harare, Zimbabwe: UNICEF and Collaborating Centre for Operational Research and Evaluation.

Malinowski, B. 1954. Magic, Science and Religion and Other Essays. New York: Anchor Books.

McCollough, M. E., Hoyt, W.T., Larson, D. B., Koeing, H. G., and Thoresen, C. 2000. "Religious Involvement and Mortality: A Meta-Analytic Review". Health Psychology 19(3):21 I-222.

Mekonnen, Y., and Mekonnen, A. 2002. Utilization of Maternal Health Care Services in Ethiopia. Calverton, Maryland, USA: ORC Macro.

Mental Health America (20I3). "Understanding the Social Determinants of Health". Retrieved July 30, 2014

from www.mentalhealthamerica.net/sites/default/...May 2013\%20Factsheet.pdf 
Musick, M. A., House, J. S., and Williams, D. R. 2004. "Attendance at Religious Services and Mortality in a National Sample". Journal of Health and Social Behaviour 45(2): 198-2I3.

National Population Commission. 2004. National Policy on Population for Sustainable Development. Abuja, Nigeria: NPopC

National Population Commission and ICF International. 2014. Nigeria Demographic and Health Survey 2013. Abuja, Nigeria and Rockville, Maryland, USA: NPopC and ICF International

Odimegwu, C. 2005. "Influence of Religion on adolescent sexual attitudes and behaviour among Nigerian University Students: Affiliation or Commitment?" African Journal of Reproductive Health 9(2): I25-I 40.

Ojua, T. A., Ishor, D. G., and Ndom, P. J. 2013. "African Cultural Practices and Health Implications for Nigeria Rural Development". International Review of Management and Business Research 2(I):176-183.

Olanisebe, S. O. 2002. "Western and Traditional Herbal Medicines in Nigeria: The Biblical Perspective". Religions: A Journal of the Nigerian Association for the Study of Religion 15 \& 16:5270.

Ononokpono, D. N., and Odimegwu, C. O. 2014. "Determinants of Maternal Health Care Utilization in Nigeria: a multilevel approach". Pan African Medical Journal I7 (Supp. I): 6- I0.

Oyedepo, D.O. 1995. Keys to Divine Health. Ikeja, Nigeria: Dominion Publishing House.

Padela, A. L., and Curlin, F. A. 20I2. "Religion and Disparities: Considering the Influences of Islam on the Health of American Muslims". Journal of Religion and Health DOI: 10.1007/s 10943 012-9620-y

Parsons, T. 1965. Religious Perspectives in Sociology and Social Psychology. In Lessa, W. A., and Vogt, E. Z. Readings in Comparative Religion: an Anthropological Approach, $2^{\text {nd }}$ edition. New York: Harper and Row

Price, J. H., McKinney, M. A., and Braun, R. E. $201 \mathrm{I}$. "Social Determinants of Racial/Ethnic Health Disparities in Children and Adolescents". The Health Educator 43(I):2-12.
Rumun, A. J. 20I4. "Influence of Religious Beliefs on Healthcare Practice". International Journal of Education and Research 2(4):37-47.

Schiller P. L., and Levin J. S. 1988. "Is There a Religious Factor in Health Care Utilization?: A Review". Social Science and Medicine 27(I2): I369-1379.

StatCorp. 2009. Stata Data-Management Reference Manual: Release 12. College Station, Texas: StatCorp LP.

Testerman, J. K. 1997. Spirituality vs Religion: Implications for Healthcare. Paper presented at the $20^{\text {th }}$ Annual Faith and Learning Seminar, Loma Linda, Califonia, June 15-27. Retrieved from July 2, $2014 \quad$ www.old.qiias.edu/ict/vol 19/19cc-283297.pdf,.

United Nations Development Programme. 20II. A Social Determinants Approach to Maternal Health: Roles for Development Actors. Retrieved September 23, 2013 from www.undp.org/Content/dam/undp/library/Democ ratic\%20Governance/Discission\%20MaternalHeal th.pdf.

Vadnais, D., Kols, A., and Abderrahim, N. 2006. Women's Lives and Experiences: Changes in the past ten years. Calverton, Maryland, USA: ORC Macro.

Walelign, D., Mekonen, A., Netsere, M., and Tarekegn, M. 2014. "Modern Contaceptive use among Orthodox Christian and Muslim Women of Reproductive age groups in Bahir Dar City, North west Ethiopia: Comparative Cross Sectional Study". Open Journal of Epidemiology 4: 235-242.

World Health Organization. 2003. Social Determinants of Health: The Solid Facts (Second edition). Retrieved September 23, 2013 from www.euro.who.int data/assets/pdffile/0005/98438/e8I384.pdf.

\section{Acknowledgement}

The authors appreciate and thank MEASURE DHS for the permission to use the NDHS dataset. 